УДК 355

\title{
ГРОЗНИЙ ІГОР,
}

кандидат економічних наук, старший науковий співробітник, завідувач відділу стратегій глобальної адаптачії

Українського інституту глобальних досліджень $і$ адаптачії

\section{ПРОКОПЕНКО РОМАН,}

кандидат економічних наук, старший науковий співробітник, провідний спечіаліст відділу стратегій глобальної адаптаиії Українського інституту глобальних досліджень і адаптачії

\section{ЕКОНОМІЧНІ НАСЛІДКИ РОСІЙСЬКО-УКРАЇНСЬКОГО КОНФЛІКТУ 2014 рОКУ}

У статті розглянуто результати російсько-украӥнського конфлікту та його вплив на знецінення національної валюти, поглиблення банківської кризи, неможливості виконання Державного Бюджету та подолання енергетичної кризи. Дано оцінку та прогноз економічного стану країни в залежності від ефективності дій Уряду щодо подолання наслідків конфрлікту. Визначено перспективні напрямки розвитку економіки України та окупованих територій в умовах політичної нестабільності.

Ключові слова: економіка; криза; очікування; політика.

Постановка проблеми. Нинішня ситуація у російсько-українських відносинах потребує формування принципово інших концептуальних, стратегічних підходів до співіснування, перегляду системи міждержавних контактів, запровадження конкретних заходів щодо протидії економічній кризі, що супроводжує російсько-українське протистояння. Російсько-український конфрлікт на сході України має безліч економічних наслідків, обумовлених як погіршенням стосунків між країнами, так і безпосередньо бойовими діями. Найсуттєвішими наслідками $є$ :

- девальвація гривні;

- банківська криза;

- провал виконання Державного бюджету;

- енергетична криза;

Не зважаючи на те, що перемир'я укладалося і легітимізувалося на світовому рівні вже декілька разів, конфлікт триває, що в свою чергу, тільки поглиблює наслідки економічної кризи.

Мета статті - визначити основні економічні наслідки російсько-українського конфллікту, дати оцінку та прогноз розвитку економіки країни в умовах політичної нестабільності.

Виклад основного матеріалу. Детальніше кожен з виділених наслідків конфлікту та його вплив на економічний стан країни та окупованих територій охарактеризуємо нижче.

Девальвація гривні.

У 2014 році гривня в середньорічному численні девальвувала в 1,47 разів або в 1,97 разів за підсумками року. Разом з об'єктивними причинами девальвації гривні, такими як падіння економіки і зростання кризових очікувань, а також загальносвітового зростання курсу долара (за 2014 р. долар зміцнився на 12,3\%, ставши лідером серед валют економічно розвинених країн) багато в чому глибина падіння курсу гривні обумовлена саме діями НБУ. Обсяг рефінансування НБУ склав у 2014 році майже 200 млрд грн, що більш ніж у 4 рази перевищує відповідний показник 2013 р. Значна частина рефрінансування була направлена комерційними банками на валютний ринок. Рефрінансування часто надавалося банкам, що не мали реальних проблем із ліквідністю. При цьому контроль рефінансування був відсутній, а заходи з адміністрування валютного ринку не здійснювалися або запізнювалися. Усе це стало причиною розкручування девальваційної спіралі.

Разом 3 тим, поряд 3 основними негативними наслідками девальвація дозволила отримати другорядні позитивні. Так, сталося зниження дефіциту зовнішньоторговельного балансу. Введення збору з операцій на придбання іноземної валюти, девальвація гривні, збільшення митних зборів, окрім інших завдань, мали на меті зниження обсягів імпорту й вирівнювання зовнішньоторговельного балансу. Обсяг імпорту в 2014 році знизився на $28 \%$. У результаті українські підприємства дістали можливість імпортозаміщення - виробництво ряду товарів в Україні суттєво зросло: цукру на 93\%, соняшникової олії на 33\%, замороженої свинини на 40\%, косметичних засобів на 40\%, пневматичних і гідравлічних інструментів і апаратури на 64\%, конвеєрних стрічок на $90 \%$, термостатів на $47 \%$ тощо. Негативним результатом при цьому $є$ істотне зниження купівельної спроможності населення на імпортні товари, що не мають українських аналогів. Також девальвація гривні спільно з підписанням угоди про асоціацію з ЄС забезпечила зростання експорту в країни $€$ С на $10 \%$ або на $1,3 \$$ млрд (за підсумками 11 місяців 2014 р.). Водночас, експорт у країни Митного союзу впав на $30 \%$ або 4,8 \$ млрд, в основному за рахунок РФ, експорт в яку скоротився на 3,7\$ млрд. Загальне падіння експорту за підсумками 11 місяців 2014 р. склало 9,4 \% або 4,8 \$ млрд. Враховуючи девальвацію гривні, $є$ підстави передбачати, що в 2015 р. об'єм українського експорту істотно зросте.

В цілому негативні наслідки від девальвації гривні на даний момент істотно перевищили всі позитивні. 
Девальвація, що продовжується, не має ніяких економічних підстав, а розкручується спекулятивними діями окремих банків та експортерів, а також кризовими очікуваннями.

Банківська криза.

У 2014 році в Україні збанкрутіли 33 банки і ще десятки опинилися в групі ризику. Враховуючи складну ситуацію у банківській системі, НБУ розширив підстави для введення кураторів для нагляду за банками, але зроблено це було дещо запізно. Частина банків належить оточенню Януковича і збанкрутіла штучно. Інші виявилися очікувано нестійкими в умовах загальноекономічної кризи. При цьому близько 14 млрд грн втратили фрізичні особи, які тримали на депозитах більше 200 тис. грн і не мають шансів отримати компенсацію 3 Фонду гарантування вкладів. Приблизно таку ж суму заборгували збанкрутілі банки юридичним особам.

У результаті фрінансово-економічної і політичної криз стався масштабний відтік депозитів. 3 початку 2014 року обсяг депозитів зменшився на $30 \%$ або на 60 млрд грн та на 9 млрд \$. Загальні активи (за порівнянним курсом) при цьому скоротилися на 17\%, фінансові результати склали більше 30 млрд гривень збитку, регулятивний капітал зменшився на 18\%. Однією з головних причин збитків крупні банки вважають окупацію АР Крим.

В умовах падіння довіри до банківської системи, диверсійних дій російських банків, девальвації гривні й масового відтоку депозитів НБУ запізнювався із заходами щодо зниження масштабів відтоку капіталу. Уведення тимчасових адміністрацій в банки з групи ризику здійснювалось 3 великою затримкою або взагалі не здійснювалося (наприклад, "Дельта-банк", проблеми в якого виникли ще на початку року, в останні місяці 2014 припинив виконувати свої зобов'язання, проте жодних заходів до нього не було прийнято).

Наприкінці 2014 року НБУ затвердив методику визначення системно важливих банків, згідно з якою до переліку системних потрапили вісім банків. Діяльність цих банків впливає на стабільність банківської системи. У випадку відмови акціонерів додатково капіталізувати ці банки у разі потреби, держава може їх націоналізувати. Враховуючи, що прийняте рішення щодо рекапіталізації за рахунок державних коштів стосується лише тих банків, активи або депозити яких складають більше 2\% від загальних по банківській системі, очікується подальше розкручування кризи й масове банкрутство дрібних банків.

У цілому прогноз розвитку банківської системи $\epsilon$ негативним. Враховуючи облікову ставку та економічну нестабільність, наразі ринок кредитування може впасти до стагнації. Також очікується епідемія неповернення валютних кредитів через девальвацію гривні та ефект доміно при банкрутстві юридичних осіб та банків. Більшість банків потребуватимуть додаткової капіталізації від акціонерів. $Є$ значна вірогідність банкрутства дочок російських банків, відтік депозитів з яких $є$ найбільшим та які, найшвидше, не будуть докапіталізовуватись власниками.

Провал виконання Державного бюджету.

Прибуткова частина Державного бюджету України в 2014 році була виконана на $94,48 \%$, загальний обсяг доходів склав 356,95 млрд грн при плані, згідно ЗУ №719-VII від 16.01.2014 "Про Державний бюджет України на 2014 рік" [1], 377,82 млрд грн. У 2013 році прибуткова частина також не була виконана, доходи Державного бюджету склали 337,79 млрд грн при плані 349,58 млрд грн [2]. Таким чином, недовиконання прибуткової частини за рік збільшилося на 9,08 млрд грн або на 2,15 процентних пункти. Сама прибуткова частина виросла з 349,58 млрд грн до 377,82 млрд грн (на 8,08\%) за планом або з 337,79 млрд грн до 356,96 млрд грн (на 5,67\%) за фрактичним виконанням.

У 2014 році двічі здійснювалися зміни доходної частини Держбюджету (табл. 1). Спочатку доходи були заплановані на рівні 395,303 млрд грн (редакція від 16.01.2014). Згідно ЗУ "Про внесення змін до Закону України "Про Державний бюджет України на 2014 рік" № 1165-18 від 27.03.2014 [3] доходи зменшено до 372,931 млрд грн. Але потім законом №1622-18 від 31.07.2014 [4] доходів збільшено до 377,821 млрд грн (головне джерело цього збільшення - трансферти від урядів зарубіжних держав і міжнародних організацій).

Податкові надходження внаслідок березневого перегляду скоротилися на 27 млрд грн, в основному за рахунок скорочення ПДВ - на 19,2 млрд грн і податку на прибуток підприємств - на 6,52 млрд грн. Часткове

Таблиця 1. - Зміни доходної частини Державного бюджету у 2014 році, млрд грн

\begin{tabular}{|c|c|c|c|}
\hline \multirow[t]{2}{*}{ Стаття } & \multicolumn{3}{|c|}{$\begin{array}{c}\text { Редакція ЗУ "Про Державний бюджет } \\
\text { України на } 2014 \text { рік» }\end{array}$} \\
\hline & 16 січня & 27 березня & 31 липня \\
\hline Разом доходів & 395,30 & 372,93 & 377,82 \\
\hline Податкові надходження & 326,27 & 299,20 & 299,59 \\
\hline Податок на прибуток підприємств & 49,62 & 43,10 & 40,29 \\
\hline Плата за користування надрами & 13,53 & 15,60 & 20,38 \\
\hline Податок на додану вартість & 177,11 & 157,91 & 149,96 \\
\hline $\begin{array}{l}\text { Акцизний податок з вироблених в Україні підакцизних } \\
\text { товарів }\end{array}$ & 33,41 & 31,63 & 31,92 \\
\hline $\begin{array}{l}\text { Акцизний податок з ввезених на митну територію України } \\
\text { підакцизних товарів (продукції) }\end{array}$ & 11,24 & 13,01 & 13,01 \\
\hline Податки на міжнародну торгівлю та зовнішні операції & 16,72 & 15,71 & 15,71 \\
\hline Неподаткові надходження & 63,43 & 68,87 & 69,37 \\
\hline Доходи від власності та підприємницької діяльності & 31,62 & 28,14 & 28,14 \\
\hline Інші надходження & 5,23 & 2,15 & 2,15 \\
\hline $\begin{array}{l}\text { Збори на обов'язкове державне пенсійне страхування } 3 \\
\text { окремих видів господарських операцій }\end{array}$ & 3,70 & 12,67 & 12,67 \\
\hline $\begin{array}{l}\text { Збір з операцій з купівлі іноземної валюти в безготівковій } \\
\text { та/або готівковій формі }\end{array}$ & 0,00 & 9,10 & 9,10 \\
\hline $\begin{array}{l}\text { Трансферти від урядів зарубіжних країн та } \\
\text { міжнародних організацій }\end{array}$ & 1,23 & 1,23 & 5,22 \\
\hline
\end{tabular}


зниження плану податкових надходжень було компенсовано збільшенням плану неподаткових доходів на 5,44 млрд грн.

Найбільш важливим аспектом прибуткової частини Державного бюджету є податкові надходження, що становлять 79\% всіх доходів. План з податкових надходжень у 2014 році був недовиконаний на $6,48 \%$ (на 19,41 млрд грн).

Основною статтею податкових надходжень $є$ податок на додану вартість, що складає $39,69 \%$ всіх доходів Державного бюджету. План зборів ПДВ був збільшений на 10,52\% - з 135,68 млрд грн в 2013 році до 149,46 млрд грн в 2014, причому фактичний збір виріс всього на $8,31 \%$. Ця стаття доходів не була виконана в 2014 на 7,29\% (на 10,93 млрд грн). Не дивлячись на те, що ціни виробників виросли на $31,8 \%$, а споживчі ціни - на 21,2\%, фактичний збір ПДВ виріс всього на $8,31 \%$ або 10,66 млрд грн. Причому об'єм невідшкодованого ПДВ в 2014 році збільшився на 4 млрд грн, а ряд платників, що входять в реєстр автоматичного відшкодування, були видалені з реєстру в ручному режимі. Незначний приріст збору, який можна назвати негативним, враховуючи випереджаюче зростання бази оподаткування, пояснюється незадовільною боротьбою 3 податковими ямами. Таким чином, робота Державної фіскальної служби зі збору податку на додану вартість $€$ незадовільною. Серед явних прорахунків, що привели до такого результату, необхідно відзначити в черговий раз відкладене уведення в дію законодавства про трансфертне ціноутворення.

На другому місці по наповненню Державного бюджету знаходиться податок на прибуток підприємств який складає $10,66 \%$ доходів і збори якого були майже виконані в 2014 році (невиконання склало 0,86\% або 0,35 млрд грн).

Акцизний збір з вироблених в Україні підакцизних товарів, що знаходиться на третьому місці за важливістю для доходів Державного бюджету, забезпечує 8,45\% надходжень. Не дивлячись на зростання акцизних ставок, ця стаття доходів не була виконана в 2014 році на $12,01 \%$ або на 3,83 млрд грн. Недовиконання плану можна пояснити розташуванням ряду найважливіших лікеро-горілчаних, виноробних та тютюнових підприємств на окупованих територіях. Збір акцизного податку з увезених до України підакцизних товарів, не дивлячись на свою не найбільшу частку в доходах $(3,44 \%)$, дозволив поліпшити ситуацію з податкових надходжень за рахунок перевиконання плану на 29,56\%. При плані 13,01 млрд грн було зібрано 16,86 млрд грн. Такий результат пояснюється рядом чинників. По-перше, були підвищені ставки акцизного збору на товари, що імпортувалися, перш за все, нафттопродукти. По-друге, девальвація гривні дозволила відповідно збільшити збір акцизів, встановлених у валюті або у відсотках від ціни товару, що ввозиться.

План збору податків на міжнародну торгівлю й зовнішні операції (4,16\% в структурі доходів держбюджету) не був виконаний, недовиконання склало 19,73\% або 3,10 млрд грн. У 2014 році сталися істотні зміни ключових чинників даної групи податків. Перш за все, на $31,6 \%$ знизився імпорт до України в доларовому численні. Також були скасовані мита на ввезення до України продукції військового призначення. Одночасно це зниження було компенсоване в гривневому еквіваленті зростанням середньорічного офріційного курсу долара на $48,55 \%$, а також уведенням нових митних ставок і оподатковуваних товарів.

План по неподаткових надходженнях в 2014 році був недовиконаний на 1,66\% (на 1,14 млрд грн). Найбільш значимими серед неподаткових статей доходів є доходи від власності та підприємницької діяльності (7,45\% від усіх доходів Державного бюджету), власні надходження бюджетних установ (5,62\% від усіх доходів), інші неподаткові надходження $(4,06 \%$ від усіх доходів) і кошти від зарубіжних країн і міжнародних організацій (1,38\% від усіх доходів). Усі ці статті доходів були виконані або перевиконані, окрім інших податкових надходжень, недобір по яких склав $18,45 \%$ (2,83 млрд грн). Це пояснюється як традиційно неякісним плануванням цієї статті (у 2013 році вона також була недовиконана на $25,22 \%$ ), так і впливом економічного спаду. У 2014 році план інших неподаткових надходжень був збільшений більш ніж удвічі (з 7,23 до 15,32 млрд грн). Це збільшення планувалося здійснити за рахунок уведення рахівниць збору з операцій з купівлі іноземної валюти (ЗУ від 27.03.2014 № 1166 "Про запобігання фінансовій катастрофрі й створення передумов для економічного зростання в Україні" [5]) у розмірі 9,1 млрд грн. Проте, враховуючи помилки в плануванні обсягу реалізації валюти, план виявився недовиконаний, за попередніми даними, на 2 млрд грн. При плануванні передбачалося, що обсяги продажів валюти будуть на рівні минулого року, проте зважаючи на девальвацію гривні й дефіцит валюти, чиста покупка валюти населенням у 2014 році склала $2,4 \$$ млрд проти 2,9 \$ млрд в 2013. На міжбанку обсяг продажу валюти знизився в 2,66 разів (з 299,37\$ млрд до 112,17 млрд) при тому, що реальний попит на валюту істотно виріс унаслідок девальвації гривні й економічної кризи. Значна частина попиту була задоволена за рахунок чорного ринку. Усе це відбилося на виконанні плану збору інших неподаткових доходів. Також надходження від збору при придбанні права власності на легкові автомобілі, запланованого на рівні 1,36 млрд грн, не виконані, зважаючи на падіння продажів легкових автомобілів на 54\% і відповідне зниження кількості реєстрацій.

В цілому, за підсумками виконання прибуткової частини Державного бюджету України на 2014 рік і порівняння його з результатами виконання бюджету 2013 року можна зробити висновок, що Україна зіткнулася з рядом нових проблем, що зумовили недовиконання бюджету. Основними з цих нових проблем були зниження економічної активності і окупація частини території. Також залишилася основна стара проблема України - висока корупція.

\section{Енергетична криза.}

У результаті бойових дій зупинились або істотно знизили видобуток вугілля 83 шахти, які давали $38 \%$ від всього обсягу вуглевидобутку. У результаті обсяг видобутку вугілля в Україні знизився на 22\%. В основному, на цих шахтах добувалось низькореакційне вугілля марок "А" і "Т". Загальне річне падіння видобутку вугілля склало 10,9 млн тонн, в основному антрацитних марок. Це негативно відобразилось на тепловій енергетиці, оскільки з 14 українських TEС 7 працюють на антрацитових марках вугілля (з них одна знаходиться на окупованій території і ще одна, Слов'янська, потребує планової довгострокової реконструкції). Річний дефіцит вугілля для роботи ТЕС склав 3,9 млн тонн. У результаті виникли перебої з енергопостачанням і секторальні відключення.

Проте необхідно відзначити, що окрім об'єктивних причин, енергокриза також мала штучні причини, що $є$ наслідком боротьби олігархічних груп. Так, не були використані можливості компенсації частини дефіциту

№ 2 (134), спецвипуск, лютий 2015 р. 
електроенергії за рахунок AEC, які працюють на даний момент на 70\% потужностей. Електроенергія, що виробляється на ТЕС, є більш дорогою та дотується 3 бюджету, тому власникам вигідніше за рахунок різноманітних схем отримувати дотації. Також було організовано інформаційну кампанію в 3 МІ $з$ приводу якості й ціни вугілля, що імпортувалося.

У цілому енергетична криза може бути достатньо легко подолана. Для цього необхідно в короткостроковій перспективі організувати імпорт дефріцитних марок вугілля і забезпечити енергобаланс за рахунок AEC. У середньостроковій перспективі необхідне переобладнання ТЕС на вугілля газових марок. Враховуючи, що більшість устаткування вугільних ТЕС зношене й неефективне, питання їх модернізації було актуальним і без вугільної кризи.

\section{Висновки}

Українсько-російські відносини перебувають у критичному непередбачуваному стані. Триває політикодипломатична конфронтація; порушені базові угоди та домовленості; фрактично зруйнована система інституційних міждержавних відносин; загострюється економічне, триває енергетичне протистояння. У цілому, нинішні реалії не дають підстав говорити про зміни на краще в осяжній перспективі. У ході дослідження де- тально розглянуто основні економічні наслідки російсько-українського конфллікту, що розпочався в 2014 році та триває до сьогоднішнього дня. Визначено згубний вплив військового протистояння для населення та економічного життя країни. Акцентовано увагу на існуванні виділених проблем протягом декількох десятиліть та їх загострення в умовах політичної нестабільності.

\section{ЛІТЕРАТУРА}

1. Про Державний бюджет України на 2014 рік : Закон України № 719-VII від 16.01.2014 // Відомості Верховної Ради. - 2014. - № 9. - С. 93.

2. Про Державний бюджет України на 2013 рік : Закон України № 5515-VI від 06.12.2012 // Відомості Верховної Ради. - 2013. - № 5-6. - С. 60.

3. Про внесення змін до Закону Україні "Про Державній бюджет Україні на 2014 рік" : Закон України № 1165-18 від 27.03.2014 // Відомості Верховної Ради. - 2014. - № 18-19. C. 694 .

4. Про внесення змін до Закону Україні "Про Державній бюджет Україні на 2014 рік" : Закон України № 1622-18 від 31.07.2014 // Відомості Верховної Ради. - 2014. - № 35. C. 1180 .

5. Про запобігання фінансовій катастрофі і створенні передумов для економічного зростання в Україні : Закон України № 1166-18 від 27.03.2014 // Відомості Верховної Ради. 2014. - № 20-21. - С. 745 .

\section{Грозный Игорь,}

кандидат экономических наук, стариий научный сотрудник, заведуюший отделом стратегий глобальной адаптации Украинского института глобальных исследований и адаптации

Прокопенко Роман,

кандидат экономических наук, старший научный сотрудник, ведущиий специалист отдела стратегий глобальной адаптации Украинского института глобальных исследований и адаптации

\section{ЭКОНОМИЧЕСКИЕ ПОСЛЕДСТВИЯ РОССИЙСКО-УКРАИНСКОГО КОНФЛИКТА 2014 ГОДА}

В статье рассмотрены результаты российско-украинского конфликта и его влияние на обесценивание национальной валюты, углубления банковского кризиса, невозможности исполнения Государственного Бюджета и преодоления энергетического кризиса. Дана оценка и прогноз экономического состояния государства в зависимости от эффективности действий Правительства в ходе преодоления последствий конфликта. Определены перспективные направления развития экономики Украины и оккупированных территорий в условиях политической нестабильности.

Ключевые слова: экономика; кризис; ожидания; политика.

Groznyi Igor,

$P h D$, senior researcher, department head of global adaptation strategies

Ukrainian Institute for Global Studies and adaptation

Prokopenko Roman,

PhD, senior researcher, leading specialist of adaptation strategies for global

Ukrainian Institute for Global Studies and adaptation

\section{ECONOMIC EFFECTS OF RUSSIAN-UKRAINIAN CONFLICT 2014}

The article describes the results of the Russian-Ukrainian conflict and its impact on the depreciation of the national currency, the deepening of the banking crisis, the impossibility of the state budget execution and overcome the energy crisis. The estimation and forecast of economic condition of the state, depending on the effectiveness of the Government in overcoming the consequences of the conflict. Perspective directions of development of economy of Ukraine and the occupied territories in the context of political instability. Proved lasting political and diplomatic confrontation; violated basic agreements and arrangements; actually destroyed the institutional system of international relations; exacerbated economic, energy continues confrontation. In general, current realities make it hard to talk about change for the better in the foreseeable future. During the investigation the devastating impact of military confrontation to the public and economic life. The attention to the existence of isolated problems for decades and their deterioration in conditions of political instability.

Key words: economy; crisis; expectations; policy.

№ 2 (134), спецьвипуск, лютий 2015 р. 
1. Vidomosti Verkhovnoi Rady (2014), № 9, st. 93 (ukr).

2. Vidomosti Verkhovnoi Rady (2013), № 5-6, st. 60 (ukr)

3. Vidomosti Verkhovnoi Rady (2014), № 18-19, st. 694 (ukr).

4. Vidomosti Verkhovnoi Rady (2014), № 35, st. 1180 (ukr).

5. Vidomosti Verkhovnoi Rady (2014), № 20-21, st. 745 (ukr).

(C) Грозний Ігор, Прокопенко Роман

Надійшла до редакції 23.01.2015

УДК. 141.7:111:130.2

ГУРЖИ КСЕНІЯ,

аспірант кафедри філософії Центру гуманітарної освіти НАН Украӥни, експерт Украӥнського інституту стратегій глобального розвитку і адаптаиіi

\title{
НЕЛІНІЙНИЙ ХАРАКТЕР ПРОЯВУ КОНФЛІКТОГЕННИХ ФАКТОРІВ У ЛОКАЛЬНИХ ПРОСТОРАХ: ОСОБЛИВОСТІ МІСЬКОГО РЕГІОНУ СОЦІАЛЬНОЇ РЕАЛЬНОСТІ
}

\begin{abstract}
У статті розглянуто місто як регіон соціальної реальності. Обґрунтовується, що міські процеси нелінійні, показано, що пошук граничних (ірраціональних) підстав функкціонування соціального порядку міської спільноти може заповнити дослідницьку лакуну в поясненні впливу нелінійних факторів та їх наслідків на зміни в соціальному бутті. Пропонується поглянути на східноукраїнський конфрлікт як на результат дії конфліктогенних чинників в купі 3 детермінованими міфом міста стратегіями поведінки городян.
\end{abstract}

Ключові слова: нелінійність; соціальна реальність; місто; міфф міста.

Постановка проблеми. Українське суспільство останніх років все частіше використовує моделі поведінки західної європейської спільноти. Це демонструють соціально-політичні події, майдани (починаючи з 2004 року) та "Революція гідності". Але за своєю соціальною актуальністю причини та наслідки таких громадянських актів все ж дещо інші, аніж ті, що "облаштовують" повсякденне життя європейця й захищають соціальний порядок європейського суспільства. Українці стикаються з тим, що таке "копіювання" приносить, інколи, протилежні результати, адже не враховано контекст країни, її історії та часу. Якщо ми згадаємо перебіг подій зими 2013-14 рр. в різних містах України, то побачимо, що процеси не просто були неоднорідними - часто вони були протилежними. Вважаємо, що названа неоднорідність виростає на ґрунті особливості локальних інтерпретацій загальнодержавних наративів, відповідно до наявної міської свідомості, того характеру, менталітету та стереотипів поведінки, що притаманні мешканцям міст.

Різні міста неоднаково реагують на ті чи інші чинники й запити. Наприклад, мешканці міст Заходу і Сходу України називають різних національних героїв й порізному визначають свої емблеми. Ми бачили, що міста, які, на думку істориків та політологів, належали до спільної історичної області та досить подібно висловлювалися на загальнодержавних виборах, по-різному реагували на, здавалося б, одні "сигнали", а подальша доля цих міст взагалі була протилежною. Сказане стосується не лише українських міст і не лише революцій- них чи воєнних подій. Констатуємо, що реакція міської свідомості, реакція того чи іншого міста на тотожні події (сигнали) є різною, непередбачуваною з точки зору логіки протікання певного соціального процесу і залежить від певних внутрішніх чинників.

Аналіз наукових публікацій, у яких започатковано вирішення проблеми. Питання нелінійних процесів вивчається в багатьох наукових дисциплінах різного спрямування. Абстрактний вимір питання нелінійності вивчається в точних науках на кшталт логіки чи математики та міждисциплінарних дослідженнях синергетичного спрямування. Свій внесок роблять суспільні та гуманітарні дисципліни, занурюючи отриману методологію до соціальної та антропологічної площини.

Дослідженню синергетики як методологічного принципу присвячені роботи В. Стьопіна [7, 8], підстави лінійних та нелінійних стратегій поведінки детально описані в працях Ю. А. Полуніна та І. Н. Тимофеєва [5], дослідженню міста, як частини складноорганізованої структури соціальної реальності покладено початок в роботах В. Туркіної [10] та Е. Сайко [6]. У цій статті використано результати статистичних та соціологічних досліджень Центру Разумкова, Агенства Research \& Branding Group, Фонду ім. Ілька Кучеріва [3, 4], матеріали журналів "Національна безпека і оборона". Також, інформативним можна вважати системний матеріал монографіії "Донбас в етнополітичному вимірі" [2]. Однак, бракує робіт, що торкаються підстав нелінійного характеру життєвих практик міської спільноти.

Метою статті $\epsilon$ експлікація тих чинників, що лежать

№ 2 (134), спецвипуск, лютий 2015 р. 